\title{
Putting Advertising and Marketing Communications Strategy into Practice: Case of Dutch Companies
}

\author{
WILLEM VERBEKE, Assistant Professor of Marketing, Erasmus University, Rotterdam; \\ ANDY MOSMANS, Marketing Communications Manager, Philips International, Eindhoven
}

Willem Verbeke and Andy Mosmans have undertaken a large survey of Dutch companies focusing on how effectively advertising and marketing communications compaigns are implemented. Their interesting results show, among other things, the extensive involvement of top management in advertising policy, that creative advertising copy is subject to little testing by managers, and that companies evaluate advertising agencies on the basis of supplying creative products. The authors conclude generally that managers use advertising less than would be expected in their marketing campaigns.

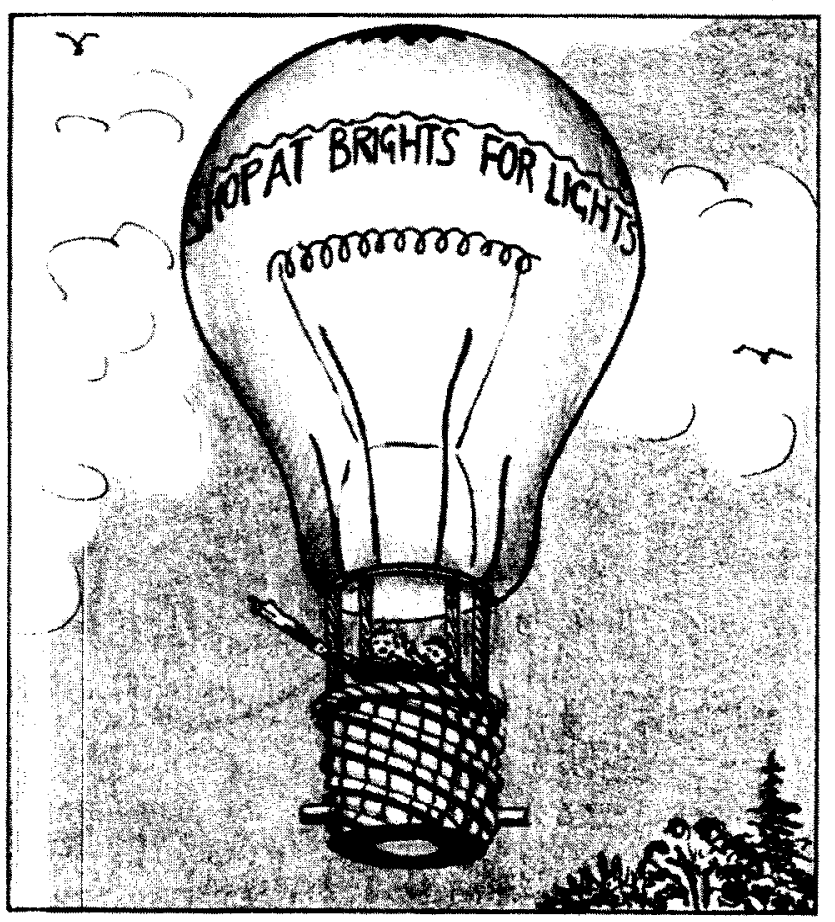

This study reflects four observations which we have made over recent years:

1. Bonoma (1985) suggested that too much research has been done on marketing strategies while too little has been done on the 'marketing strategy implementation' process.

2. Many marketing communication managers in the Netherlands have expressed to us their uncertainty concerning how advertising and marketing communication campaigns should be implemented. For instance, they frequently ask what budget methods their colleagues or competitors are using.

3. Lodish (1986) made some thought-provoking suggestions with regard to how managers could improve the effectiveness of their marketing communications by means of better implementation strategies. Subsequently, we began to wonder how Dutch managers were coping with this problem.

4. 'Marketing' as a profession originated in the US; now many managers and academics wonder how marketing strategies are implemented in Europe. As a result, we began to analyse how marketing communications decisions are made within the Dutch companies.

As the reader will notice, we use the term 'marketing communications campaign' to refer to different kinds of marketing communication instruments, including advertising, sales promotion, direct marketing, and others. At this time, a majority of Dutch marketing communications agencies offer a portfolio of communications services. Subsequently, we feel that the term 'marketing communications' is appropriate for our purposes. In the first part of the paper, we will describe in general terms the population under study. We will then cover the following areas which relate to the market- 
ing communication and advertising implementation process:

1. The degree to which management is involved in the communciation/advertising implementation process.

2. Communication budgeting methods.

3. Communication and advertising's share within the total marketing budget.

4. Methods used to test the advertising campaign.

5. The use of 'competition' between advertising agencies (also called shopping).

6. Performance assessment of the advertising agency.

7. The compensation of marketing communications and advertising agencies.

8. The 'make or buy' decision as it relates to the various marketing communications instruments.

\section{The Population of The Study}

This study is based upon a questionnaire that was sent to 500 Dutch companies of different sizes (sales volume) and types (product or service orientations). Within the various size and type categories, a random sample was taken. A response rate of $25 \%(n=123)$ was attained. For most topics we used closed questions (multiple choice questions), but for a number of other topics we used open questions. The questionnaire asked firms - selling multiple brands - to take one of their brands as representative for study purposes. At the same time, however, one brand name could involve more than one product. Therefore, we told them that when this was the case, they should apply the questionnaire to one product within one brand. Based upon both considerations we began to use the term: a one brand/product combination. The number of respondents per position within the company is given in Table 1 . The distribution of companies by sales volume is given in Table 2 and the distribution of companies by industry is given in Table 3 . Because in every questionnaire not all the questions were completed, the number of questions answered will be mentioned beneath each table.

\section{The Marketing Communication and Advertising Implementation Process}

\section{Management Involvement in the Communication Policy}

Several views have been expressed on the subject of which members of the company should be involved in the marketing communications campaign. Bonoma (1985), for instance, suggests the 'cascade' model (see Figure 1).

According to Bonoma's model, the implementation of an overall corporate business strategy serves as the foundation for a corporate marketing strategy which subsequently serves as the strategic starting-point for
Table 1 Positions of the Persons Interviewed

\begin{tabular}{lc}
\hline Respondent's position & $\begin{array}{c}\text { Frequency } \\
\text { (percentage) }\end{array}$ \\
\hline 1. Marketing manager & $46 \%$ \\
2. General manager & $20 \%$ \\
3. Head of advertising/communication & $12 \%$ \\
4. Other & $12 \%$ \\
5. Product manager & $10 \%$ \\
\hline$(n=112)$ &
\end{tabular}

Table 2 The Distribution of Sales Volume of the Companies Studied

\begin{tabular}{llc}
\hline Sales class & $\begin{array}{c}\text { Frequency } \\
\text { (percentage) }\end{array}$ \\
\hline$<50$ & million guilders & $(54 \%)$ \\
$50-100$ & million guilders & $(23 \%)$ \\
$100-250$ & million guilders & $(6 \%)$ \\
$250-500$ & million guilders & $(5 \%)$ \\
$500-750$ & million guilders & $(1 \%)$ \\
$>750$ & million guilders & $(11 \%)$ \\
\hline
\end{tabular}

$(n=119)$

Table 3 The Distribution by Industry of the Companies Studied

\begin{tabular}{lc} 
Company & $\begin{array}{r}\text { Frequency } \\
\text { (percentage) }\end{array}$ \\
\hline 1. Food and agriculture industry & $16 \%$ \\
2. Consulting and service industry & $15 \%$ \\
3. Electronics industry & $9 \%$ \\
4. Retailing & $7 \%$ \\
5. Chemical industry & $6 \%$ \\
6. Banking and insurance industry & $5 \%$ \\
7. Construction industry & $5 \%$ \\
8. Equipment industry & $4 \%$ \\
9. Other industries & $33 \%$ \\
\hline
\end{tabular}

$(n=123)$

Figure 1 The Cascade Model of Bonoma

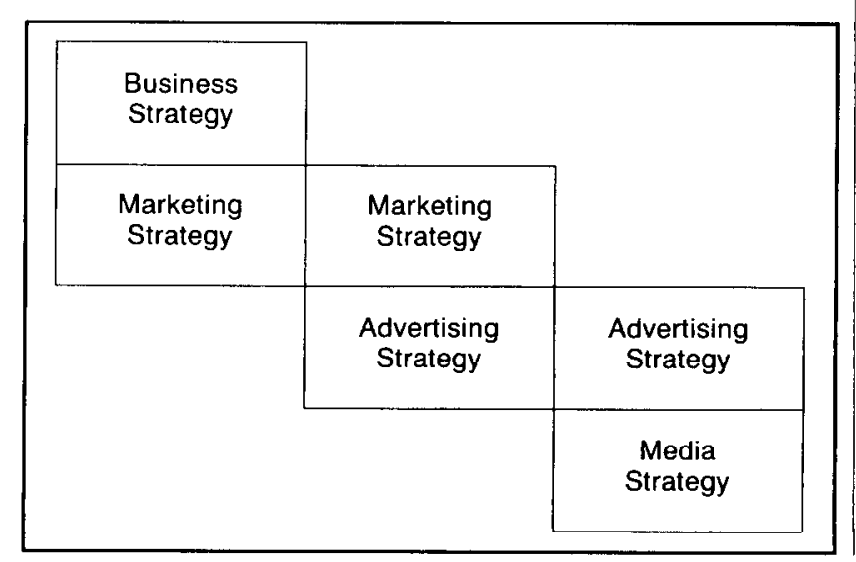


lower level marketing communication strategies. The strategy and implementation are both interrelated in time inside the company. In time, the method of implementation influences and limits but also directs the marketing strategy (called the structure-strategy discussion). Within this framework, communication/ advertising management is taken into consideration only at lower levels, that is, corporate management is not supposed to make any advertising decisions. At the corporate level, the broad strategic framework, or 'mission', in which advertising will be embedded, is formulated. Bunoma states, however, that corporate management must closely monitor how the strategy is being implemented at lower levels.

A lew' remarks will now be made concerning Bonoma's perspective:

- Capable marketing managers are promoted very rapidly to higher positions (Sculley, 1987). This creates a vacuum of competence in which new managers do not possess sufficient knowledge and experience related to corporate marketing policy. Thus out of necessity, corporate management must concern itself with advertising policy.

- The delegation of marketing functioning inside small companies usually differs from that inside large companies. Out of necessity, the management of small corporations will perform both strategic and operational tasks.

- Increasingly, it is being realised that advertising affects the corporate image of the company (integrated communication). This is another reason for corporate management to give more attention to advertising policy (Lodish, 1986).

In Tables 4 and 5 we present data relating to who actually implements advertising campaigns. The extensive involvement of top management in advertising pulicy is apparent. It might have been the case, however, that only in small firms were top managers involved in marketing communications and advertising campaigns. As Table 5 shows, however, top managers are involved regardless of the size of the firm.

\section{The Determination of the Communication Budget}

As part of our study, we examined how managers determine communication/advertising budgets. A number of different methods can be distinguished in the communication/advertising management literature:

A. Percentage of previous sales/profit method.

$B$ Percentage of expected sales/profit method.

(. Buyer's potential method.

[?. Objective and task method (reach, recall).

E. Competitive parity method.

F. All you can afford method.

Because the advantages and disadvantages of these methods are widely published (see for instance Aaker
Table 4 Persons Involved in the Communication/ Advertising Policy

\begin{tabular}{lr} 
Position & $\begin{array}{c}\text { Frequency } \\
\text { (percentage) }\end{array}$ \\
\hline 1. Top management & $87 \%$ \\
2. Marketing manager & $84 \%$ \\
3. Product manager & $74 \%$ \\
4. Sales manager & $70 \%$ \\
5. Sales person & $47 \%$ \\
6. General manager & $40 \%$ \\
\hline
\end{tabular}

$(n=120)$

Table 5 Top Management's Involvement in the Communication/Advertising Campaign according to Sales Volume

\begin{tabular}{lccc}
\hline & \multicolumn{3}{c}{ Sales volume } \\
\cline { 2 - 4 } $\begin{array}{l}\text { Frequency } \\
\text { (percentage) }\end{array}$ & $<50$ & $50-100$ & $>100$ \\
\hline
\end{tabular}

$(n=93)$

Table 6 Method of Determination for Communication/Advertising Policy

\begin{tabular}{lcc}
\hline & $\begin{array}{c}\text { Frequency } \\
\text { (number) }\end{array}$ & $\begin{array}{c}\text { Frequency } \\
\text { (percentage) }\end{array}$ \\
\hline 1. Percent previous sales/profit & 15 & $13 \%$ \\
2. Percent expected sales/profit & 55 & $47 \%$ \\
3. Buyer potential & 19 & $16 \%$ \\
4. Communicalion objectives as & & \\
reach & 49 & $41 \%$ \\
5. Communication objectives as & 19 & $16 \%$ \\
6. Cocall & 14 & $12 \%$ \\
7. All you can afford & 41 & $35 \%$ \\
8. Other & 21 & $17 \%$ \\
\hline
\end{tabular}

$(n=118)$

and Meyers, 1987), it is not appropriate to discuss them here. In Table 5, we present our research data relating to these problems. As the reader might notice, some companies use more than one budget method, which is why the percentages add up to more than $100 \%$. From the table, we can see that the percentage of 'expected sales/profit method' is used most frequently, followed in order by the 'objective and task method' and the 'all you can afford method'. Despite their popularity, however, the 'percentage of expected sales method' and the 'all you can afford method' have many well known drawbacks (for an overview, see Aaker and Meyers, 1987).

\section{The Communication/Advertising Budget as Part of the Total Sales of the Company}

As part of our study, we wanted to answer the question: how much do Dutch companies spend on marketing 


\section{Table 7 Marketing Communication's Share of Sales}

$\%$ Expenditure on

Marketing Communication

Frequency

(percentage)

$\begin{array}{rr}<5 \% & 55 \% \\ 5-10 \% & 29 \% \\ 10-15 \% & 5 \% \\ 15-20 \% & 5 \% \\ >20 \% & 6 \%\end{array}$

$(n=116)$

Table 8 Advertising's Share in the Total Communication Budget

$\%$ Expenditure on advertising

Frequency

\begin{tabular}{lc}
\hline$<20 \%$ & (percentage) \\
$21-40 \%$ & $12 \%$ \\
$41-60 \%$ & $22 \%$ \\
$61-80 \%$ & $26 \%$ \\
$>80 \%$ & $20 \%$ \\
\hline
\end{tabular}

$(n=108)$

communication as a percentage of sales for specific product/brand combinations. Our findings appear in Table 7. We also examined advertising's share in the total communication budget. These findings appear in Table 8 .

Since we studied both industrial and fast-moving consumer goods firms (see Table 3), these data are not surprising. Within industrial companies, direct selling plays a more important role than advertising, something which is not the case in fast-moving consumer goods firms. This explains the variation in advertising budgets within our sample.

\section{Pre-Testing and Post-Testing of Creative Copies}

The quality (or impact) of the creative copy forms a success factor of a marketing strategy (Lodish, 1986). Thus, it is important to invest sufficient time and money to develop and guarantee this quality. In this article, we will give this topic considerable attention.

Gross (1972), who has been outspoken on this subject, alleges that several creative alternatives should be generated, since the creative process is an area where improvement is often both possible and necessary. Such improvement, however, is directly related to the share resources which are allocated to the creative process as part of the total advertising budget. It is also directly related to the manner in which the creative process is eventually implemented. In the development of the advertising campaign, managers must choose between two main strategies relating to implementation of the creative process:
- to design, produce and test one creative sample,

- to design, produce and test several creative samples.

In the latter case, it is assumed that there is a considerable variance in effectiveness between the alternative samples, which can be estimated by pre-testing.

Gross has formulated a mathematical model by which he hypothesises that an insufficient percentage of the total advertising budget (an average of $5 \%$ ) is spent on creativity. He recommends that additional money budgeted for creativity should be spent on designing, producing and testing several alternatives in order to maximise productivity and effectiveness.

The choice of the number of creative alternatives to be developed is determined by comparing the marginal profit generated by each alternative to the additional required to develop each alternative. To do this, some model parameters should be estimated, specifically:

- the distribution in quality and effectiveness among the alternatives,

- the costs of generating and testing the alternatives,

- the validity and reliability of the test methods.

Therefore, we sought to determine to what extent creative advertising messages are tested and in which stage the various creative copies are pre-tested. Relevant data are presented in Table 9. From these data we can

Table 9 Testing and Assessing Creative Copies

(a) Are creative copies tested (pre- \& post-)

\begin{tabular}{lcc}
\hline & $\begin{array}{c}\text { Frequency } \\
\text { (number) }\end{array}$ & $\begin{array}{c}\text { Frequency } \\
\text { (percentage) }\end{array}$ \\
\hline Yes & 52 & $45 \%$ \\
No & 64 & $55 \%$ \\
\hline
\end{tabular}

$(n=116)$

(b) How many creative copies are tested and in which stage of development?

Cases Frequency Percentage positive $A Q^{*} T P^{*}$

1. One copy roughly

2. Several copies roughly completed $n=43 \quad 34 \quad 79 \% \quad 28 \%$

3. One copy thoroughly completed

$n=31$

21

$68 \% \quad 17 \%$

4. Several copies thoroughly completed $n=32 \quad 21 \quad 66 \% \quad 17 \%$ 5. Post-testing of copies $n=49 \quad 33 \quad 67 \% \quad 27 \%$

*TP = Total population

$A Q=$ Answered Questions $(n=52)$ 


$\begin{aligned} & \text { Table } 10 \\
& \text { Tested }\end{aligned}$
\begin{tabular}{llllll} 
No. of copies & 1 & 2 & 3 & 4 & 5 \\
\hline Frequency (number) & 0 & 7 & 15 & 5 & 1 \\
\hline
\end{tabular}

$(n=28)$

Table 11 The Number of Thoroughly Completed Creative Copies Tested

\begin{tabular}{llllll} 
No. of copies & 1 & 2 & 3 & 4 & 5 \\
\hline Frequency (number) & 0 & 7 & 7 & 2 & 0 \\
\hline
\end{tabular}

$(n=16)$

conclude that less than half the companies test any creative copies at any stage, but when testing is done, it is most often done on several roughly completed creative copies.

The frequencies in connection with the number of copies tested (for both roughly and thoroughly completed alternatives) are given in Tables 10 and 11. The data clearly show that relatively little testing of creative copies is done and that, when tests are done, relatively few alternatives are considered. Thus, we must conclude that the creative potential of the advertising agency is not being adequately utilised. According to Gross' theory, this could result in relatively low quality advertising. Furthermore, the quality of the testing itself is quite problematic, since the criteria used to evaluate creative copies are not always well chosen, as revealed in Table 12

The method most used by companies to test creative copies against these criteria was the so-called 'depth interview'; this test method is often qualitative in character because consumers are usually asked to respond to the advertisement verbally. We have three questions to raise in regard to its effectiveness:

1. Will the depth interview and criteria predict consumer's actual market behaviour? If so, the test method is valid.

Table 12 Criteria Used to Evaluate Coples During Pre-Testing

\begin{tabular}{lc} 
Criterion & $\begin{array}{c}\text { Number of times } \\
\text { mentioned }\end{array}$ \\
\hline Concept message/recognition & 10 \\
Understanding of message/recall & 6 \\
Brand/product position awareness & 3 \\
Impact/effective reaction & 7 \\
Willingness to try & 1 \\
Penetration/frequency of use & 1 \\
Purchase & 1 \\
\hline (n=29) &
\end{tabular}

2. Is it possible to recapitulate the test results repeatedly? If so, the test method is reliable. (Note: not a single company as revealed by responses to our questionnaire imposed validity or reliability standards within this framework.)

3. Are the criteria compatible with the long-term objectives of the enterprise? In this connection, Lodish (1986) speaks about 'vaguely right' as opposed to 'precisely wrong' criteria. The first category of criteria is hard to measure but relates well with the long-term objectives of the enterprise (e.g. repeat purchase). The second category, on the other hand, relates less well with the long-term objectives of the enterprise but is easy to measure (e.g. recall, recognition, etc.). Unfortunately; in practice we see that the second category is used most.

\section{Agency Competition or Shopping}

As previously mentioned, Gross believes it is advisable to create and test different strategic concepts and unfinished creative copies before implementing an advertising campaign. In theory, the greatest 'sales variance' among the alternatives should arise when alternative advertising campaigns are created by different agencies.

To learn more about this subject, we asked companies to what extent and for what reasons they organise agency competitions. This question was open-ended and was answered by 73 respondents. Fifty-two companies stated that they did not organise agency competitions. When asked to explain their reasons for not doing so, they gave answers which have been tabulated in Table 13

Table 13 Reasons for Not Using Agency Competition

Reasons

Frequency (number)

The present relationship is good

33

No budget available

No review of the long-term relationship/ performance of the agency needed at that time

$(n=52)$

Table 14 Reasons for Agency Competition

Reasons

Frequency (number)

To pick best execution of the communications strategy Wide choice/knowledge of talents Variance in creativity

$(n=27)$ 
Twenty-one companies, however, did organise an agency competition. The principal reasons (which were stated in response to open-ended questions) for this are presented in Table 14

In the future, it is to be expected that agency competition will increase for the following reasons.

- 'Quality' is generally receiving more emphasis (Buzzell and Gale, 1987). Therefore, companies will begin to demand more from the advertising agency.

- The corporate environment is increasingly subject to change (Peters, 1987). As a result, the advertising strategy that results from the enterprising and marketing strategy will be adjusted more frequently (Verbeke, 1987). In other terms, pressure to display innovative behaviour in the marketing communications agencies will become very crucial in the future (Kanter, 1989).

\section{Assessment of Ad Agency Performance}

Inspired by a former study (Verbeke, 1988) in which it became apparent that companies are particularly concerned with evaluating agencies on the basis of creativity, we were interested in verifying this observation. Therefore, we asked companies what functions they perceived as crucial when hiring an advertising agency. Responses to this question also allowed us to identify the following:

- Those factors considered most important when hiring an advertising agency (see Table 15), and

- those factors considered crucial to the success or failure of the advertising campaign.

The results of this study and an earlier study (Verbeke, 1988 ) are very similar. The following conclusions can be made

- Creative performances and media services appear

Table 15 Factors in Hiring a Communication/Advertising Agency

\begin{tabular}{|c|c|c|c|c|c|c|}
\hline \multirow[b]{2}{*}{ Applicability level } & \multicolumn{6}{|c|}{ positive responses* } \\
\hline & 0 & 1 & 2 & 3 & 4 & 5 \\
\hline \multicolumn{7}{|l|}{ 1. Good creative } \\
\hline performances & 9 & - & 1 & 3 & 49 & 59 \\
\hline 2. Good media services & 14 & 2 & 4 & 25 & 56 & 18 \\
\hline 3. Contribution to increased & & & & & & \\
\hline market share & 33 & 1 & 6 & 29 & 28 & 20 \\
\hline 4. Package of services & 26 & 10 & 35 & 40 & 7 & 一 \\
\hline $\begin{aligned} \star 0 & =\text { not applicable } \\
1 & =\text { very unimportant } \\
2 & =\text { unimportant } \\
3 & =\text { neutral } \\
4 & =\text { important } \\
5 & =\text { very important } \\
(n=116) & \end{aligned}$ & & & & & & \\
\hline
\end{tabular}

to be more important than contribution to the market share increase and a package of services.

- The most valued function of the advertising agency consists mainly of supplying creative products rather than rendering a variety of communication services.

- Even though companies view long-term sales as their principal objective, it appears that the advertising campaign is not assessed in accordance with this objective (this agrees with our hypothesis).

\section{Compensation of the Advertising Agency}

We framed the compensation issue in terms of how it affects the relationship between advertiser and agency. An effective compensation system should meet the objectives of both. Calantone and Drury (1979) recognise the mutual objectives shown in Table 16. The problems in connection with the compensation schemes for advertising agencies are conceptually similar to the compensation problems of the sales organisation.

A much used method of compensating the advertising agency is the so-called $15 \%$ commission. Lodish (1986) feels that this method is flawed because the interests of the communication agency and the advertiser will not coincide since agencies benefit directly from higher budgets. Furthermore, there is a risk that the advertising agency will purchase media that involve lower administrative costs. In both cases, the client's long-term objectives are not taken into account.

In addition to this well-known and frequently used $15 \%$ commission system, we can distinguish a number of other currently used compensation methods:

- The flat fee system:

On the basis of negotiation, an agreed fixed fee is reached. The problem here is that the quantity

Table 16 Compensation scheme objectives (according to Calantone and Drury)

Advertiser

1. Value must be received for the money spent

2. Costs must be predictable and controllable

3. Charges must be easy to verify

4. An atmosphere must be provided for unbiased recommendation and efficient purchasing

5. Agencies should have incentive to use time efficiently
Communication agency

1. Sufficient income must be provided to cover cost and provide a profit

2. Continuity and predictability of income

3. Billings must be easy to calculate and verify

4. Agency must be permitted to maintain control of its management prerogatives

5. Client should have incentive to utilise agency's time efficiently 


\section{Table 17 Schemes used by Companies to Compensate Agencies}

\begin{tabular}{lcc} 
Compensation scheme & $\begin{array}{c}\text { Frequency } \\
\text { (number) }\end{array}$ & $\begin{array}{c}\text { Frequency } \\
\text { (percentage) }\end{array}$ \\
\hline 1. Commission basis & 47 & $42 \%$ \\
2. Flat fee & 43 & $35 \%$ \\
3. Hourly rate & 52 & $42 \%$ \\
4. Results incentive & 2 & $2 \%$ \\
5. Guaranteed profit per- & 16 & $14 \%$ \\
$\quad$ centage of the capitalised & & \\
$\quad$ sales & & \\
\hline
\end{tabular}

$(n:=112)$

of services to be performed is hard to determine in advance, so that one of the two parties could suffer.

- The hourly rate system:

The advertising agency presents the advertiser with an invoice based on hourly rate. As with the commission system, the danger here is that the advertising agency may perform more services than are desired.

- The results incentive system:

The starting-point is the outlining of a task, for instance reaching a certain level of product/brand preference or a certain level of sales. The difficulty here is that it is hard for the advertising agency to evaluate performance since other factors may also influence the results.

- The guaranteed percentage of the capitalised sales profit system:

The agency receives a percentage of those sales increases supposedly attributable to the advertising campaign.

Tahle 17 shows which compensation schemes are used must often.

Based on these results, we can draw the following conclusions.

- The compensation schemes most criticised (commission basis, flat fee and hourly rate) are used most frequently.

- Companies develop combinations of compensation schemes. This can be inferred from the fact that the percentages add up to more than $100 \%$.

\section{'Make' or 'Buy' Decisions of the Communication and Advertising Campaign}

The make-or-buy decisions related to the marketing communications services are very complex. Three questions were asked:

- Which services are bought, which partly, which not (make or buy)?

- Why are services bought?
- From whom are services bought (cooperation structures)?

Tables 18 and 19 reveal the buy patterns of the communication mix and the advertising campaign. The tables show that companies buy a differentiated and hybrid portfolio of services. No fixed pattern can be distinguished. A model that tries to give insight into this decision-making problem has been developed by Anderson and Weitz (1986). Their model explains why a complex portfolio of bought services arises by relating the make-or-buy decision to multiple key variables, such as competition in the supplier market, company-specific capabilities, economies of scale and environmental uncertainty. Based upon their conceptual model, they conclude that hybrid make-or-buy decisions are likely to emerge. Our data verify their conclusions.

In the Netherlands it is well known that advertising agencies are skilled in positioning brands for their clients, but when asked how they themselves are positioned in the market they are often unable to provide an answer. The above-mentioned buying patterns, as well as other observations, might provide the basis for a segmentation and positioning strategy by the marketing communications agencies themselves.

- Clients can be classified on the basis of different segmentation criteria. For instance, the market can be divided into industrial versus fast-moving clients and/or into companies that buy some or all of their needs. On the basis of this segmentation, certain communication agencies will target particular segments. Thus the communication agency population will become more heterogeneous.

- There is room for both full service and specialised communication agencies. The first group will mainly target businesses that buy all their needs. The second group, on the other hand, will target precisely those businesses that buy only part of their needs. Lodish (1986) has discussed in depth both the advantages and disadvantages related to integration versus specialisation.

Table 20 shows that cooperative links are made by companies with their marketing communication agencies. We can note that, in addition to their regular advertising agencies, Dutch companies also buy communications services from other specialised communication agencies. We again see that companies buy a differentiated or hybrid portfolio of services.

\section{Conclusion}

In conclusion, we can state that Dutch advertising managers are quite involved with their advertising campaigns. This might indicate that for many Dutch managers advertising plays an important role within their marketing campaigns. However, when we look at the methods managers use to implement their campaigns, the picture is not so positive. We agree with Bonoma that the implementation of marketing strategies 
Table 18 Buying Pattern of the Communication Mix

\begin{tabular}{|c|c|c|c|c|}
\hline & \multicolumn{4}{|c|}{ Number of respondents to whom the following applies } \\
\hline & $\begin{array}{c}\text { Not } \\
\text { applicable }\end{array}$ & $\begin{array}{l}\text { Bought } \\
\text { entirely }\end{array}$ & $\begin{array}{l}\text { Bought } \\
\text { in part }\end{array}$ & Not bought \\
\hline 1. Direct mail & $(25 \%)$ & $(7 \%)$ & $(43 \%)$ & $(25 \%)$ \\
\hline 2. Trade promotion & $(31 \%)$ & $(8 \%)$ & $(38 \%)$ & $(23 \%)$ \\
\hline 3. Consumer promotion & $(42 \%)$ & $(8 \%)$ & $(36 \%)$ & $(16 \%)$ \\
\hline 4. Advertising & $(6 \%)$ & $(52 \%)$ & $(37 \%)$ & $(5 \%)$ \\
\hline 5. Public relations & $(14 \%)$ & $(8 \%)$ & $(37 \%)$ & $(41 \%)$ \\
\hline
\end{tabular}

$(n=112)$

\section{Table 19 Buying Pattern of the Advertising Campaign}

\begin{tabular}{lcccc}
\hline \multicolumn{2}{c}{$\begin{array}{c}\text { Number of respondents to whom the following applies } \\
\text { Not } \\
\text { applicable }\end{array}$} & $\begin{array}{l}\text { Bought } \\
\text { entirely }\end{array}$ & $\begin{array}{l}\text { Bought } \\
\text { in part }\end{array}$ & Not bought \\
\hline 1. Creative concept testing & $(32 \%)$ & $(40 \%)$ & $(16 \%)$ & $(12 \%)$ \\
2. Pre-testing & $(42 \%)$ & $(37 \%)$ & $(11 \%)$ & $(10 \%)$ \\
3. Media planning & $(9 \%)$ & $(36 \%)$ & $(35 \%)$ & $(20 \%)$ \\
4. Production creativity & $(12 \%)$ & $(63 \%)$ & $(20 \%)$ & $(5 \%)$ \\
5. Post-testing & $(39 \%)$ & $(39 \%)$ & $(12 \%)$ & $(10 \%)$ \\
6. Market research & $(16 \%)$ & $(16 \%)$ & $(39 \%)$ & $(29 \%)$ \\
\hline
\end{tabular}

$(n=110)$

Table 20 Kinds of Cooperative Links between Companies and Communication/Advertising Agencies

\begin{tabular}{lcc}
\hline Cooperative links & $\begin{array}{c}\text { Frequency } \\
\text { (number) }\end{array}$ & $\begin{array}{c}\text { Frequency } \\
\text { (percentage) }\end{array}$ \\
\hline 1. Regular advertising agency & 97 & $82 \%$ \\
2. Project-oriented advertising agency & 21 & $18 \%$ \\
3. Marketing consultant & 14 & $12 \%$ \\
4. Direct-mailing specialist & 19 & $16 \%$ \\
5. Promotion agency & 29 & $24 \%$ \\
6. Creative workshop & 14 & $12 \%$ \\
7. Media-buying service & 10 & $9 \%$ \\
8. Market research agency & 51 & $43 \%$ \\
\hline (n=118) & &
\end{tabular}

does indeed continue to be a crucial problem for Dutch marketing managers.

\section{Note}

The authors wish to extend special thanks to G. Minekus (Prad), G. Derksen M.A. (IPM) and J.M.D. Koster M.A. (School of Economics, Erasmus University) for their valuable remarks during this study.

\section{References}

Aaker, D. and Meyers, J., Advertising and Promotion Management, New York, Prentice-Hall, 1987.
Anderson, E. and Weitz, B., Make-or-Buy Decisions: Vertical Integration and Marketing Productivity, Sloan Management Review, Spring, 1986, pp. 3-19.

Bonoma, T. The Marketing Edge, New York, Macmillan, 1985 Buzzell, R. and Gale, B., The Pims Principles, New York, Free Press, 1987.

Calantone, R. and Drury, D., Advertising Agency Compensation: A Model for Incentive and Control, Management Science, July, 1979, pp. 632-642.

Farris, P. and Buzzell, R. Why Advertising and Promotional Costs Vary: Some Cross-sectional Analysis, Journal of Marketing, 43, Fall, 1979.

Gross, I., The Creative Aspects of Advertising, Sloan Management Review, Fall, 1972, pp. 83-109.

Kanter, R., When Giants Learn to Dance, New York, Simon \& Schuster, 1989. 
Lontish, L., The Advertising and Promotion Challenge, New York, Oxford University Press, 1986

Peters. T., Thriving on Chaos, New York, Macmillan, 1986.

Sculley, J., Odyssey: Pepsi to Apple ... A Journey of Adventure, ldeas and the Future, New York, Harper \& Row, 1987.

Verbeke, W., Adaptive and Experimental Learning Method for Advertising Management, (in Dutch) Adformatie, 60, 1987, 60-64.

Verbeke, W., Developing an Advertising-Client Relationship in the Netherlands, Journal of Advertising Research, 28/6, 1988 , pp. $19-27$.

Verbeke, W. and Mosmans, A., The Dutch Advertiser is more Critical these Days, (in Dutch) Holland Harvard Business Review, 18, pp. 93-97.

Verbeke, W., Mosmans, A. and Verhulp, M., Marketing Communication Management within Dutch Companies (in Dutch), Erasmus University Economical Papers, 1988.

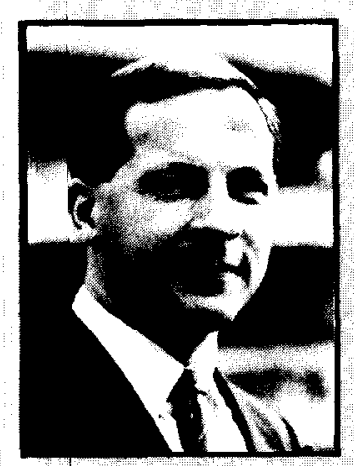

WILLEM VERBEKE, Erasmus University, Postbus 1738, 3000 Rotterdam, Netherlands

Dr Willem Verbeke is a faculty member of the Department of Marketing, Erasmus University. His research interests are in marketing communications and complexity in marketing. Author of a number of scientific papers, he was Visiting Professor at the ISBN, Penn State University, USA, in 1990.

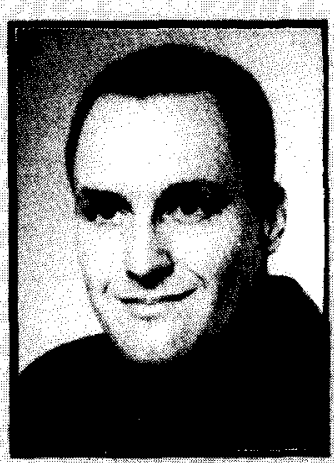

ANDY MOSMANS, Marketing Communications Manager, Philips International, Eindhoven

Andy P. Mosmans Ir. graduated with a degree in business economics from the Erasmus University of Rotterdam. He has published in the Harvard Holland Review and lectured at the EMAC conference. His research interests are: push and pull systems in marketing communications and expert systems for advertising campaign development. Currently he is marketing communications manager with Philips consumer electronics. 